\title{
3. Revision of the Code of Good Practice on Referendums
}

\author{
Nicos C. Alivizatos
}

In October 2016, under the impact of the Brexit referendum, the Venice Commission took the initiative to update its Code of Good Practice on Referendums from 2007 (Code). ${ }^{1}$ For that purpose, it first adopted a questionnaire asking for information on the latest developments in the member states. On the basis of the answers, a first exchange occurred.

In parallel, the Parliamentary Assembly of the Council of Europe adopted a report titled 'Updating guidelines to ensure fair referendums in Council of Europe member states', ${ }^{2}$ which led to a Resolution with the same title, adopted on 22 January $2019 .^{3}$

In her opening speech, the rapporteur, Dame Cheryl Gillan, MP, insisted that the updated Code should reflect changes that had occurred since 2007 'so it can continue to provide modernized guidelines for all our members' ${ }^{4}$ In his address during the same debate, Gianni Buquicchio, the president of the Venice Commission, referred to two eminent Swiss personalities originating from the same city, Geneva, Rousseau and Fazy. He claimed that the former's unreserved support for the people's direct involvement in political decision-making through referendums should not obscure the historical fact that whenever representative government was weakened, democracy was sooner or later abolished. Should one recall the latter's poisonous aphorism that referendums are, in reality, 'l'appel de l'intelligence à l'ignorance'?5

Study No. 371/2006, CDL-AD(2007)008rev-cor.

7 January 2019, Doc. 14791.

Resolution 2251 (2019).

PACE, Winter Session 2019, Tuesday, 22 January 2019, Sitting No 3.

Ibid. James Fazy's famous phrase is mentioned in PACE, Référendums: vers de bonnes pratiques en Europe, Documents de séance, Doc 10498, Session ordinaire de 2005, 25-29 avril 2005, Vol. III, 397. 
More concretely, in that Resolution, the Parliamentary Assembly invited the Venice Commission to take into account the following fundamental principles:

1. that referendums should be embedded in the process of representative democracy, that is, complement rather than substitute it;

2. that proposals put to a referendum should be as clear as possible and subject to detailed prior scrutiny; and

3. that campaign rules should ensure a balance between the different sides and guarantee that voters have access to balanced and quality information.

Both in America and in Europe, the period preceding the adoption of that Resolution was marked by systematic attacks, originating from both extremes of the political spectrum, against the so-called 'elites', including 'bankers', 'the rich' and the 'Brussels bureaucrats', members of parliament, ministers and party leaders. A very evocative example of an attack of such a type is the following extract from President Trump's inaugural address, in January 2017:

Politicians prospered, but the jobs left and the factories closed. The establishment protected itself, but not the citizens of our country. Their victories have not been your victories; their triumphs have not been your triumphs; and while they celebrated in our nation's capital, there was little to celebrate for struggling families all across our land. ${ }^{6}$

In other words, until President Trump was elected, laws were allegedly voted in Washington, and decisions were taken, not to the benefit of the people but in the interest of the few. 'Today's ceremony', the newly elected president went on,

has very special meaning. Because today we are not merely transferring power from one administration to another, or from one party to another - but we are transferring power from Washington, D.C. and giving it back to you, the American people. ${ }^{7}$

This crude flattery of the people is also behind the glorification of referendums as the only proper means to ensure the direct and, hence, genuine expression of the people's will. In an interview before the 2017 French presidential election, Marine Le Pen announced that, if she was elected, she would call two referendums immediately after her advent to power. ${ }^{8}$ On the left, Alexis Tsipras,

6 Remarks of President Donald J Trump, inaugural address, 20 January 2017, https://www.whitehouse.gov/briefings-statements/the-inaugural-address/, accessed 22 June 2020.

7 Ibid.

8 The first on France's withdrawal from the EU, the so-called 'Frexit' (see Ingrid Melander, 'Far right FN party calls for French "Frexit" referendum on EU', Reuters, 24 
the former Greek prime minister, before his shift to pragmatism, in 2018-19, promised to provide for no less than five different types of referendums in the country's amended constitution he was at the time contemplating. Because, as he explained, in democracies, decisions must be taken by the people and not by technocrats. ${ }^{9}$

The other dramatic developments that the rapporteurs of the amended Code could not ignore were technological innovations, which had profoundly changed the democratic landscape, such as the new reality of social media, in parallel with the increased access to information by the voters.

Finally, globalization has had a very significant impact on voting behaviour, through facilitating direct and indirect involvement of 'third' parties in voting procedures, including referendum campaigns. For instance, Russia has been accused of involvement not only in the 2016 US presidential campaign, but also in the 2018 referendum in North Macedonia, which concerned that Balkan country's name. Not surprisingly, even in countries with longstanding traditions of fair and impartial elections, there have been very serious complaints of violation of the relevant rules, in particular financial regulations. In the United Kingdom, for instance, more than two years after the 2016 referendum, the Electoral Commission imposed fines amounting to no less than $£ 61,000$ and $£ 70,000$ on pro-Brexiteers in respect of serious offences in breach of the rules on campaign spending. ${ }^{10}$

Therefore, in drafting the revised Code, the Venice Commission has focused primarily on procedural guarantees aiming to ensure the fairness of referendums. The need for an independent and impartial body, which would be in charge of organizing the referendum from national level to polling station level, was stressed, in particular for countries without a longstanding tradition of administrative authorities' impartiality in electoral matters. Starting from checking the validity and appropriateness of the questions proposed for referendum, that body's powers should include supervision of the referendum

June 2016, www.reuters.com.article/US-france-lepen-referendum-idUSKCN1190UW, accessed 30 July 2020), and the second on the amendment of the French Constitution for the purpose of introducing the principle of 'national preference', that is, the precedence of French nationals in hiring, dispensing of housing and other benefits (see Nicholas Vinocur, 'President Marine Le Pen's first 100 days', Politico, 20 April 2017, www.politico.eu/article/president-marine-lepens-first-100-days-hypothetical-french -election, accessed 30 July 2020).

9 Statement by Prime Minister Alexis Tsipras of 25 July 2016 (in Greek), http:// primeminister.gr/2016/07/25/15039, accessed 30 July 2020.

10 Electoral Commission, 'Vote Leave fined and referred to the police for breaking electoral law', 17 July 2018, www.electoralcommission.org.uk/media-centre/vote -leave-fined-and-referred-police-breaking-electoral-law, accessed 30 July 2020. 
campaign, enforcing the rules and timely sanctioning of possible breaches as the only efficient means of avoiding faits accompli.

Moreover, whenever a text is put to the vote at the request of a part of the electorate, parliament must be able to give a non-binding opinion on the text put to the vote.

As far as substantive limits are concerned, in the opinion of the Commission, the text submitted to a referendum should comply with superior law and must not be contrary to international law, including the Council of Europe's statutory principles, as interpreted by the European Court of Human Rights. For the complexity of the questions that may arise in that context, one may take a look at the important debates that occurred in Switzerland in 2009 on the occasion of the referendum on the ban of minarets and in Greece in 2015 on the occasion of the referendum on the bailout conditions proposed to Greece by the International Monetary Fund, the European Central Bank and the European Commission.

To conclude, a reference should be made to the statistics on national referendums of the LIDD project, grouped by country, since $1990 .{ }^{11}$ As expected, with 274 referendums, Switzerland is far ahead at the top. First among all other countries comes Azerbaijan, with 69 referendums, and last come Monaco, Germany and Belgium, with no referendums at all. Whatever one's preferences are in relation to referendums, one cannot easily assert that, in terms of democracy, the first is more advanced than the latter are. 2020.

1 See http://lidd-project.org/data/, (tab 'referendum practice') accessed 22 June 